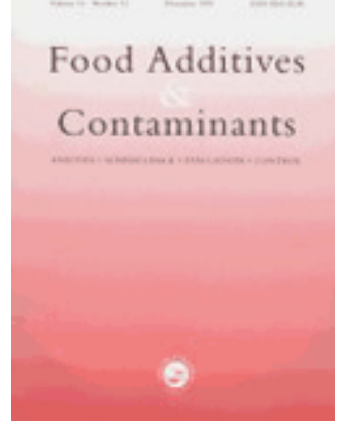

\title{
Assessing human exposure to phthalic acid and phthalate esters from mineral water stored in polyethylene terephthalate and glass bottles
}

\begin{tabular}{|c|c|}
\hline Journal: & Food Additives and Contaminants \\
\hline Manuscript ID: & TFAC-2007-107.R1 \\
\hline Manuscript Type: & Original Research Paper \\
\hline $\begin{array}{r}\text { Date Submitted by the } \\
\text { Author: }\end{array}$ & 20-Jun-2007 \\
\hline Complete List of Authors: & $\begin{array}{l}\text { Montuori, Paolo; University of Naples "Federico II", Department of } \\
\text { Preventive Medical Sciences } \\
\text { Jover, Eric; I.I.Q.A.B.-C.S.I.C., Environmental Chemistry } \\
\text { Department } \\
\text { Morgantini, Marcello; University of Naples "Federico II", Department } \\
\text { of Preventive Medical Sciences } \\
\text { Bayona, Josep Maria; I.I.Q.A.B.-C.S.I.C., Environmental Chemistry } \\
\text { Department } \\
\text { Triassi, Maria; University of Naples "Federico II", Department of } \\
\text { Preventive Medical Sciences }\end{array}$ \\
\hline Methods/Techniques: & Clean-up - SPME, GC/MS, Survey \\
\hline Additives/Contaminants: & Phthalates \\
\hline Food Types: & Drinking water, Water \\
\hline
\end{tabular}

\section{SCHOLARONE \\ Manuscripts}




\title{
Assessing human exposure to phthalic acid and phthalate esters from mineral water stored in polyethylene terephthalate and glass bottles
}

\begin{abstract}
Phthalic acid and phthalate esters are of growing interest due to their significant usage and their potential toxicity. Polyethylene terephthalate (PET) and glass are both widely used materials for bottled drinking water. In this study, phthalic acid (PhA), bis(2-ethylhexyl) phthalate (DEHP), dimethyl phthalate (DMP), diethyl phthalate (DEP), diisobutyl phthalate (DiisoBP) and dibutyl phthalate (DBP) were analyzed in a large number of Italian bottled water samples. These samples showed different concentrations of phthalates being are nearly twenty times higher in samples bottled in PET than the ones from glass bottles with total levels of phthalates of 3.52 and $0.19 \mu \mathrm{g} \mathrm{L}^{-1}$ respectively. However, the observed levels do not represent a significant exposure pathway when considering the US Environmental Protection Agency (EPA) reference dose [an estimate of a daily oral exposure to the human population (including sensitive sub-groups) that is likely to be without an appreciable risk of deleterious effects during a lifetime]. Also, no significant correlation was found between the phthalate concentrations and the physicochemical properties of the different water samples, apart from the still/sparkling water parameter for the PET samples. In this instance, slightly higher concentrations were observed for the PET bottled still water samples than for the sparkling water samples although no explanation has been found yet.
\end{abstract}

Key words: Bottled water, Polyethylene terephthalate, Phthalic acid, Phthalate esters, SPME, EI GC-MS. 


\section{Introduction.}

The bottled water industry in European countries and North America has expanded over the last 30 years, and it is also increasing rapidly in many developing countries (FDA, 2003). Consumption reached $155 \mathrm{~L}$ per capita per year in Italy, $136 \mathrm{~L}$ in Mexico, $112 \mathrm{~L}$ in France, $123 \mathrm{~L}$ in Belgium, $99 \mathrm{~L}$ in Germany, $98 \mathrm{~L}$ in Spain, $97 \mathrm{~L}$ in Switzerland and $63 \mathrm{~L}$ in the United States in 2000/2001 (Potera, 2002 and Thurman et al., 2002).

In Italy, as in many developed countries, polyethylene terephthalate (PET) is widely used as a container for commercial bottled water, and its use is also increasing rapidly due to its lower production costs in comparison to glass containers (Petrelli et al., 2006). PET is synthesized by reacting ethylene glycol $\left(\mathrm{C}_{2} \mathrm{H}_{6} \mathrm{O}_{2}\right)$ with either terephthalic acid or its methyl ester catalysed by antimony oxide. The reaction is carried out under vacuum at high temperatures to achieve high molecular weight polymers. Some studies have shown PET decomposition and phthalate migration in the absence of an accurate temperature and humidity control during PET synthesis (Castle et al., 1989 and Calà et al., 2003). Other studies have shown that water, PET bottled, can release phthalate additives used in the plastic molding process especially in critical conditions of use (e.g. long storage times) (Sauvant et al., 1995 and Biscardi et al., 2003) as already shown for PVC (Hakkarainen, 2003).

Phthalates display a variety of toxic effects in animal studies including decreased fertility in females (Biscardi et al., 2003), fetal defect (Saillenfait et al., 2001) and reduced survival of offspring (Gray et al., 2000), altered hormone levels (Thompson et al., 2004), uterine damage (Seidlova-Wuttke et al., 2004) and male reproduction abnormalities such as reduced sperm production and motility (Sharpe et al., 1995), Sertoli cell damage (Heindel and Powell, 1992), Leyding cell tumors (Jones et al., 1993), cryptorchidism and hypospadias which may be manifestations of one condition termed as "testicular dysgenesis syndrome" (Skakkebaek et al., 2001). The effects of human exposure to phthalates have not been fully studied (Colon et al., 2000; Health Care Without Harm, 2002; Duty et al., 2003b). Long latency periods between relevant exposures and health impacts, unquantified exposures, and subtle effects that are difficult to detect are added difficulties to the few 
existing epidemiological studies of phthalate toxicity in humans (Health Care Without Harm, 2002). In one of these few human studies, phthalates were investigated as a cause of precocious puberty in young Puerto Rican girls (Colon et al., 2000). In this study, the serum levels of phthalates obtained from 41 girls with premature appearance of breast tissue were compared with 35 controls. Phthalate esters were detected in $68 \%$ of the cases and in the $17 \%$ of the controls and they were found significantly lower levels of phthalates than the cases. For the bis(2-ethylhexyl)phthalate (DEHP), the average concentration was $70 \mathrm{ppb}$ in the controls compared to $450 \mathrm{ppb}$ in the cases. Even if the study conclusions were limited due to small population size and the possibility of contaminated serum samples, the association between phthalates and premature thelarche is biologically plausible. Two studies present the first human data which demonstrate that phthalates are associated with increased DNA damage in sperm (Duty et al., 2003a; Duty et al., 2003b). Finally, a recent study concludes that monobenzyl phthalate (MBzP) exposure was significantly associated with a $10 \%$ decrease in follicle stimulating hormones (FSH) concentration in adult men (Duty et al., 2005). Furthermore, phthalates are chemicals of concern also due to their large production volume and to a non negligible human intake which has been estimated, for example, ranging from 2 to $10 \mu \mathrm{g} / \mathrm{kg}$ bw/day of dibutyl phthalate (DBP) for the U.S. population (NTP-CERHR, 2006) and from 3 to $30 \mu \mathrm{g} / \mathrm{kg}$ bw/day for DEHP (Latini, 2005). In order to assess the safety issues of food containing phthalates their intake can be compared to the reference doses (RfD) defined by the US-EPA. The RfD being an estimate of a daily oral exposure to the human population (including sensitive subgroups) that is likely to be without an appreciable risk of deleterious effects during a lifetime. European Union has included several phthalates as priority substances for evaluation (European Union, 2006) and dibutylphtalate has been proposed by the Committee on the Environment, Public Health and Food Safety to be included as a priority substance in the Water Framework Directive 2000/60/EC (European Union, 2007).

Solid-phase microextraction (SPME) is a solvent free pre-concentration technique, which has recently been applied to the extraction of phthalates from aqueous matrices (Kelly and Larroque, 1999). However, liquid-liquid extraction (LLE) (Jobling et al., 1995; Castillo and Barcelo, 1997) with dichloromethane or hexane, and solid-phase extraction (SPE) (Jobling et al., 1995; Holadova and Hajslova, 1995; Castillo and Barcelo, 1997; Castillo et 
al., 1998) are usually applied. Nevertheless, a source of error of particular concern for phthalic acid and phthalate esters determination is their high levels in the procedural blanks originating from laboratory plastics, solvents and polymeric sorbents from the preconcentration techniques (Durand and Barcelo, 1993; Castillo et al., 1998). In this way, the US Environmental Protection Agency (EPA) reports that DEHP, along with other common phthalate esters, cannot be accurately or precisely measured at concentrations below $2 \mu \mathrm{g} \mathrm{L}-$ 1, due to high blank levels when the conventional methods LLE or SPE are employed (Lawrence, 1995), and at the same time the EPA has established a maximum concentration limit (MCL) in drinking water of $6 \mu \mathrm{g} \mathrm{L}^{-1}$ in its National Primary Drinking Water Regulations (NPDWR) (EPA, 1991). Nowadays, phthalates are not considered in the European Union drinking water regulations even if, dibutylphtalate has been proposed by the Committee on the Environment, Public Health and Food Safety to be included as a priority substance in the Water Framework Directive 2000/60/EC (European Union, 2007). Recent studies show that detection limits well below this level can be achieved when using SPME coupled to GC-MS (Peñalver et al., 2000; Alzaga et al., 2003). In this way, SPME diminishes the risk of contamination in the extraction of phthalates since it is a solvent free technique and it minimizes the materials use, which can be potentially polluted with phthalates (e.g. SPE cartridges, solvents). At present, there are different published papers in which the suitability of SPME phthalate esters extraction from water is shown (Moder et $a l .$, 1998) and even coupled to GC-MS (Peñalver et al., 2000; Peñalver et al., 2001; Suzuki et al., 2001; Alzaga et al., 2003;) and to LC-UV (Kayali et al., 2006). However, in these studies only a small number of bottled water samples were analyzed in order to evaluate the developed methodology. Recently, stir bar sorptive extraction (SBSE) technique has been used to analyze phthalates in water obtaining lower limits of detection than with SPME due to its higher volume of polymeric phase compared to SPME but as a drawback, it needs a dedicated analytical instrumentation (Serodio et al., 2003; Serodio et al., 2006).

The aim of this study was to determine the phthalic acid and phthalate esters content in Italian mineral water both bottled in glass or in PET bottles. Moreover, the relevance of bottled water consumption in human exposure to phthalic acid and phthalate esters will be assessed. For this reason, phthalic acid ( $\mathrm{PhA})$ as the main degradation product of diesters, bis(2-ethylhexyl) phthalate (DEHP), dimethyl phthalate (DMP), diethyl phthalate (DEP), 
diisobutyl phthalate (DiisoBP) and dibutyl phthalate (DBP) have been analyzed in Italian samples of commercial mineral water stored in PET and in glass bottles using SPME in combination with GC-MS. To the best of our knowledge this study represents the first survey in which phthalic acid and phthalate esters, in an extensive sample pool, were investigated by using SPME and GC-MS.

\section{Material and methods.}

\section{Study area and sampling.}

The survey was conducted in Italy and a variety of commercial bottled water samples were collected. Commercial bottled water samples included different water type, such as spring water, mineral water, light water (low mineralization water) and sparkling water from miscellaneous commercial brands. The sampling of each commercial brand was carried out twice, packed in polyethylene and in glass bottles. A total of 71 commercial brands coming from 16 different Italian regions were collected. Therefore, 142 samples, 71 packed in PET and 71 in glass containers were analysed.

\section{Sample preparation and analysis}

Water samples $(5 \mathrm{~mL})$ were placed in a $7 \mathrm{~mL}$ glass vial and $\mathrm{pH}$ was adjusted at $\mathrm{pH} 2$ by using $\mathrm{HCl}$ and were continuously stirred using a magnetic stirrer. Immersion SPME was carried out using the polydimethylsiloxane- divinylbenzene (PDMS/DVB) fibre from Supelco (Bellefonte, PA, USA) adapting an already reported methodology (Peñalver et al., 2001). After an extraction of $20 \mathrm{~min}$ at $25^{\circ} \mathrm{C}$ the fibre was thermally desorbed at $250^{\circ} \mathrm{C}(3$ min splitless time) in the GC-MS standard split/splitless injector. The analysis was carried out using a quadrupole GC-MS QP5050A Shimadzu (Kyoto, Japan) with a GC-MS (version 1.1, data acquisition software ), working in the electron impact mode at $70 \mathrm{eV}$. A SPB 20 (20\% diphenyl 80\% dimethylpolysiloxane) $(60 \mathrm{~m}, 0.25 \mathrm{~mm}$ ID) coated with a 0.25 $\mu \mathrm{m}$ film thickness column was used. The gas chromatographic conditions were as follow. The initial oven temperature was $50^{\circ} \mathrm{C}$ for $2 \mathrm{~min}$, then programmed from $50^{\circ} \mathrm{C}$ to $250^{\circ} \mathrm{C}$ at $10^{\circ} \mathrm{C} \mathrm{min}^{-1}$ with a final holding time of $30 \mathrm{~min}$. MS transfer line and ion source were kept at $250^{\circ} \mathrm{C}$. Acquisition was carried out in the single ion monitoring mode using two characteristic ions for each target analyte. Compound identification was carried out 
comparing their retention times with standards, using two characteristic ions and their ratio for each target analyte. Furthermore, for the samples presenting higher concentrations, target analytes identity was confirmed in full-scan mode (m/z range from 60 to 350). Quantification was done by using the external calibration method showing linear correlations with $\mathrm{R}^{2}>0.98$ for all the target analytes from 0.01 to $1 \mu \mathrm{g} \mathrm{L}{ }^{-1}$.

Data analysis was performed with the statistical software SPSS (release 13.0, SPSS Inc., Chicago, IL, USA). All data was presented as the mean \pm SD. The level of significance was set at $P \leq 0.05$.

Procedural blanks were carried out and used for the calculation of the detection limits (LOD). They ranged from $0.01 \mu \mathrm{g} \mathrm{L} \mathrm{L}^{-1}$ for the DBP to $0.08 \mu \mathrm{g} \mathrm{\textrm {L } ^ { - 1 }}$ for phthalic acid and quantification limits (LOQ) ranged from $0.02 \mu \mathrm{g} \mathrm{L}^{-1}$ for DEHP to $0.1 \mu \mathrm{g} \mathrm{L}^{-1}$ for phthalic acid.

\section{Results \& Discussion}

Despite few data being available, the results reported here are compared in Table 1 with bibliographic phthalate concentrations for tap and bottled water. It is important to point out that the scarcity of data on this topic is mainly due to the analytical difficulties in the phthalate determination. In this way, the large number of non-detected samples in the USA National Resources Defence Council study (NRDC, 2006) (DEHP was not detected in $98.5 \%$ of the samples) is explained by the high detection limits of the applied methodologies (e.g. EPA $2 \mu \mathrm{g} \mathrm{L}^{-1}$ ). However, for the most studied compounds such as DEP, DnBP and DEHP the results found in this study are in agreement with the literature.

The use of SPME GC-MS as analytical technique achieved lower detection limits due to its improved blank level. In this way, lower target analytes concentrations were detected 
avoiding the production of a large number of non-detected samples as occurred in the NRDC study (NRDC, 2006).

In Table 2 the quartiles are shown of the target analytes concentrations for the glass and PET bottled water. PET bottled water shows, as expected, a higher content for all phthalates, being $\mathrm{PhA}$, degradation product of the phthalates esters, the most abundant individual compound. Box plots of the different target analytes concentrations depending on bottle material are shown in Figure 1. In this figure, it is evident that higher concentrations are found for all the analysed phthalates in the PET bottled water. However, these differences were confirmed using statistical tools and significant differences (MannWhitney test $\mathrm{p}<0.05$ ) were found between glass and PET for all the compounds. It should be pointed out, that also different phthalate patterns were obtained in the two cases (Figure 2). For the PET bottles PhA (69\%) and DnBP (10\%) are the most abundant compounds and for the glass bottles the most abundant are DiisoBP (25\%) and the DnBP (15\%). In both cases, the lowest concentrations were found for DEHP, which was always far below the EPA regulation limit of $6 \mu \mathrm{g} \mathrm{L}^{-1}$ with a maximum of $0.17 \mu \mathrm{g} \mathrm{L}^{-1}$ for PET bottles and of $0.02 \mu \mathrm{g} \mathrm{L}^{-1}$ for glass bottles. These results confirm that the use of PET containers is the main cause of higher concentrations of phthalates in bottled water, as the concentration of the sum of the studied compounds is more than twelve times higher in PET than in glass bottled water. The presence of phthalates in glass bottled water could come from the other water processing steps (PVC tubing, storage tanks, filtration steps, cap-sealing). In the case of PET, four different bottle volumes have been sampled $(0.75,1,1.5$ and $2 \mathrm{~L})$ but no correlation was found between the bottle volume and the phthalate content. Moreover, no correlation was found between the phthalates content and several water physicochemical parameters such as conductivity, $\mathrm{pH}$, solid residue, sodium, calcium, potassium, magnesium, chlorine, fluorine, sulphates, carbonates, nitrates and silicates (data taken from the bottle label). Therefore, it could be considered that these parameters are not relevant in controlling the leaching of the phthalates from the bottle to the water.

No significant differences were found between sparkling and still waters when there was no segregation of the data between PET and glass containers. However, when considering PET 
bottles alone, DEP was found to be significantly higher in still water $(n=55)$ than in sparkling water $(\mathrm{n}=16)(\mathrm{p}<0.05)$. Until now, no reason has been found, to explain this result.

From a toxicological point of view, and considering that a MCL is only available for DEHP (6 $\mu \mathrm{g} \mathrm{L}^{-1}$ EPA limit for drinking water), the concentrations found are lower. Another way to assess the health impact of phthalates is to study the importance of drinking PET bottled water referred to the EPA available phthalates reference doses (RfD) (EPA, 2006) (0.1 $\mathrm{mg} / \mathrm{kg} / \mathrm{day}$ for the DnBP, $0.8 \mathrm{mg} / \mathrm{kg} /$ day for the DEP, $2 \mathrm{mg} / \mathrm{kg} / \mathrm{day}$ for $\mathrm{PhA}$ and 0.02 $\mathrm{mg} / \mathrm{kg} /$ day for DEHP). In this way, we will consider a body weight of $70 \mathrm{~kg}$ and a daily water consumption of $2 \mathrm{~L}$. In Table 3 , it is shown the proportion of the different RfDs, which can be achieved by drinking PET bottled water. The results show that, due to the low phthalate concentrations, PET bottles do not represent any health risk related to the phthalate intake as they do not contribute significantly to the estimated RfD. The maximum expected contribution will be $0.051 \%$ of the RfD for the DnBP and only for the most contaminated sample. However, it is important to point out the lack of data on this subject and the need of further studies involving both food analysis and epidemiological research to estimate the phthalates uptake in a comprehensive way.

\section{Conclusions}

Due to analytical difficulties in achieving low detection limits, there is a lack of data on the phthalate occurrence in drinking water. The use of SPME and GC-MS as an analytical technique has proven to be suitable for the analysis of phthalates at low concentrations and for a large number of samples. The use of PET bottles has been clearly correlated with the concentration of phthalates in the bottled water. In this way, phthalates concentrations are significantly higher (nearly twenty times) in this water than in glass bottled water. However, the concentrations found do not represent any risk for human health as can be seen by comparing the concentrations found to the existing EPA regulation (only available for DEHP) or by referring to the EPA RfDs. The contribution from drinking water is 
always below $0.1 \%$ of the RfD for all the target analytes. Therefore, the main conclusion of this study is that Italian bottled water does not represent a relevant ingestion source of phthalates esters and phthalic acid for the population who consume bottled water. Due to similarities in the materials being used and in the technologies in water processing industries all around Europe, similar conclusions to the ones presented here should be expected for the whole European Union.

\section{Acknowledgements}




\section{References}

Alzaga R, Peña A, Bayona JM. 2003. Determination of phthalic monoesters in aqueous and urine simples by solid-phase microextraction-diazomethane on-fibre derivatization-gas chromatography-mass spectrometry. Journal of Separation Science 26:87-96.

Biscardi D, Monarca S, De Fusco R, Senatore F, Poli P, Buschini A, Rossi C, Zani C. 2003. Evaluation of the migration of mutagens/carcinogens from PET bottles into mineral water by Tradescantia/micronuclei test, Comet assay on leukocytes and GC/MS. Science of the Total Environment 302:101-108.

Calà PG, Mantelli F, Sciullo A. 2003. I controlli chimici e chimico-fisici delle acque minerali naturali. Atti della 24a Giornata di Studio di Ingegneria Sanitaria - Ambientale "Acque confezionate per il consumo umano" Facoltà di Ingegneria, Università degli Studi di Brescia.

http://dirgex05.arpat.toscana.it/acqua/ac_usoumano_documenti_controlli_acquaminerali_br escia_122003.pdf (article in italian) Accessed 2007 Mar 15.

Casajuana N, Lacorte S. 2003. Presence and release of phthalic esters and other endocrine disrupting compounds in drinking water. Chromatographia 57:649-655.

Castillo M, Barcelo D. 1997. Analysis of industrial effluents to determine endocrinedisrupting chemicals. Trends in Analytical Chemistry 16:574-583.

Castillo M, Oubina A, Barcelo D. 1998. Evaluation of ELISA kits followed by liquid chromatography atmospheric pressure chemical ionization mass spectrometry for the determination of organic pollutants in industrial effluents. Environmental Science \& Technology 32:2180-2184.

Castle L, Mayo A, Gilbert J. 1989. Migration of plasticizers from printing inks into foods. Food Additives \& Contaminants 6:437-443. 
Colon I, Caro D, Bourdony CJ, Rosario O. 2000. Identification of phthalate esters in the serum of young Puerto Rican girls with premature breast development. Environmental Health Perspectives 108:895-900.

Durand G, Barcelo D. 1993. Solid-phase extraction using C18 bonded silica disks interferences and analysis of chlorotriazines in seawater samples. Talanta 40:1665-1670.

Duty SM, Silva MJ, Barr DB, Brock JW, Ryan L, Chen Z, Herrick RF, Christiani DC, Hauser R. 2003a. Phthalate exposure and human semen parameters. Epidemiology 14:269277.

Duty SM, Singh NP, Silva MJ, Barr DB, Brock JW, Ryan L, Herrick RF, Christiani DC, Hauser R. 2003b. The relationship between environmental exposures to phthalates and DNA damage in human sperm using the neutral comet assay. Environmental Health Perspectives 111:1164-1169.

Duty SM, Calafat AM, Silva MJ, Ryan L, Hauser R. 2005. Phthalate exposure and reproductive hormones in adult men. Human Reproduction 20:604-610.

Environmental Protection Agency (US), National Primary Drinking Water Regulations; Fed. Reg., Part 12, 40 CFR Part 141, (p 395), Washington, DC, 1 July 1991.

European Union, Comission Recommendation, 2006/283/EC.

European Union, Committee on the Environment, Public Health and Food Safety, Final Report A6-0125/2007.

Food and Drug Administration, Federal Register 68 (2003) 9873.

Gray Jr LE, Ostby J, Furr J, Price M, Veeramachaneni DN, Parks L. 2000. Perinatal exposure to the phthalates DEHP, BBP, and DINP, but not DEP, DMP, or DOTP, alters sexual differentiation of the male rat. Toxicological Sciences $58: 350-365$. 
Hakkarainen M. 2003. Qualitative and quantitative solid-phase microextraction gas chromatographic-mass spectrometric determination of the low-molecular-mass compounds released from poly(vinyl chloride)/polycaprolactone-polycarbonate during ageing Journal of Chromatography A 1010:9-16.

Health Care Without Harm. Aggregate exposures to phthalates in humans. (2002). http://www.noharm.org/library/docs/Phthalate_Report.pdf Accessed 2007 Mar 15.

Heindel JJ, Powell CJ. 1992. Phthalate ester effects on rat sertoli-cell function-invitro effects of phthalate side-chain and age of animal. Toxicology and Applied. Pharmacology 115:116-123.

Holadova K, Hajslova J. 1995. A comparison of different ways of sample preparation for the determination of phthalic-acid esters in water and plant matrices. International Journal of Environmental Analytical Chemistry 59:43-57.

Integrated Risk Information System, US Environmental Protection Agency, http://www.epa.gov/iris/subst/ Accessed2007 Mar 15.

Jobling S, Reynolds T, White R, Parker MG, Sumpter JP. 1995. A variety of environmentally persistent chemicals, including some phthalate plasticizers, are weakly estrogenic. Environmental Health Perspectives. 103:582-587.

Jones HB, Garside DA, Liu R, Roberts JC. 1993. The influence of phthalate-esters on leydig-cell structure and function in-vitro and in-vivo. Experimental and Molecular Pathology 58:179.

Kayali N, Tamayo FG, Polo-Díez LM. 2006. Determination of diethylhexyl phthalate in water by solid phase microextraction coupled to high performance liquid chromatography. Talanta 69:1095-1099. 
Kelly MT, Larroque M. 1999. Trace determination of diethylphthalate in aqueous media by solid-phase microextraction-liquid chromatography. Journal of Chromatography A 841:177-185.

Latini G. 2005. Monitoring phthalate exposure in humans. Clinica Chimica Acta 361:2029.

Lawrence HK. 1995. EPA's Sampling and analysis methods database, $2^{\text {nd }}$ edition. Monroe, Georgia (USA): CRC Press/Lewis Publishers. p 40.

Luks-Betlej K, Popp P, Janoszka B, Paschke H. 2001. Solid-phase microextraction of phthalates from water. Journal of Chromatography A 938:93-101.

Moder M, Popp P, Pawliszyn J. 1998. Characterization of water-soluble components of slurries using solid-phase microextraction coupled to liquid chromatography mass spectrometry. Journal of Microcolumn Separations 10:225-234.

National Resources Defence Council NRDC. http://www.nrdc.org/water/drinking/bw/appa.asp Accessed 2007 Mar 15.

NTP-CERHR Monograph on the Potential Human Reproductive and Developmental Effects of Di- $n$-Butyl Phthalate (DBP). Center for the Evaluation of Risks to Human Reproduction (CERHR), http://cerhr.niehs.nih.gov/chemicals/phthalates/dbp/DBP_Monograph_Final.pdf Accessed 200 Mar 14.

Peñalver A, Pocurull E, Borrull F, Marce RM. 2000. Determination of phthalate esters in water samples by solid-phase microextraction and gas chromatography with mass spectrometric detection. Journal of Chromatography A 872:191-201.

Peñalver A, Pocurull E, Borrull F, Marce RM. 2001. Comparison of different fibers for the solid-phase microextraction of phthalate esters from water. Journal of Chromatography A 922:377-384. 
Petrelli F, Grappasonni I, Morichetti L, Cocchioni M. 2006. Evoluzione normativa Della disciplina delle acque destinate al consumo umano. Annali di Igiene 15:923-931 (in italian).

Potera C. 2002. The price of bottled water. Environmental Health Perspectives, 110:A76A76.

Saillenfait AM, Langonne I, Leheup B. 2001. Effects of mono-n-butyl phthalate on the development of rat embryos: In vivo and in vitro observations. Pharmacology \& Toxicology $89: 104-112$.

Sauvant MP, Pepin D, Bohatier J. 1995. Chemical and in-vitro toxicological evaluations of water packaged in polyvinyl-chloride and polyethylene terephthalate bottles. Food Additives Contaminants 12:567-584.

Seidlova-Wuttke D, Jarry H, Wuttke W. 2004. Pure estrogenic effect of benzophenone-2 (BP2) but not of bisphenol A (BPA) and dibutylphthalate (DBP) in uterus, vagina and bone. Toxicology 205:103-112.

Serodio P, Nogueira JMF. 2004. Multi-residue screening of endocrine disrupters chemicals in water samples by stir bar sorptive extraction-liquid desorption-capillary gas chromatography-mass spectrometry detection. Anal. Chim. Acta 517:21-32.

Serodio P, Nogueira JMF. 2006. Considerations on ultra-trace analysis of phthalates in drinking water. Water Research 40:2572-2582.

Sharpe RM, Fisher JS, Millar MM, Jobling S, Sumpter JP. 1995. Gestational and lactational exposure of rats to xenoestrogens results in reduced testicular size and sperm production. Environmental Health Perspectives 103:1136-1143.

Skakkebaek NE, Rajpert-De Meyts E, Main KM. 2001. Testicular dysgenesis syndrome: an increasingly common developmental disorder with environmental aspects. Human Reproduction 16:972. 
Suzuki T, Yaguchi K, Suzuki S, Suga T. (2001). Monitoring of phthalic acid monoesters in river water by solid-phase extraction and GC-MS determination. Environmental Science \& Technology 35:3757-3763.

Thompson JC, Ross SM, Gaido, KW 2004. Di(n-butyl)phthalate impairs cholesterol transport and steroidogenesis in the fetal rat testis through a rapid and reversible mechanism. Endocrinology 145 :1227-1237.

Thurman RB, Athanasopoulos AA, Allan MS, Atchia, SM (2002). Bottle wars: England versus Scotland versus France. International Journal of Food Sciences and Nutrition, 53:209-216. 


\section{Figure legends}

Figure 1. Box plots showing the phthalates concentrations depending on the bottle material.

Figure 2. Normalised phthalates patterns for the PET and the glass bottled water.

13
14
15
16
17
18
19
20
21
22
23
24
25
26
27
28
29
30
31
32
33
34
35
36
37
38
39
40
41
42
43
44
45
46
47
48
49
50
51
52
53
54
55
56
57
58
59
60


Table I. Comparison of bibliographic data on phthalates content in tap and bottled water. Presented results are the mean of the different analysed samples expressed in $\mu \mathrm{g} \mathrm{L}^{-1}$.

\begin{tabular}{|c|c|c|c|c|c|c|c|c|c|}
\hline$\left(\mu \mathrm{gL}^{-1}\right)$ & $\begin{array}{c}\text { NRDC, } \\
2006 \\
\text { Bottled } \\
\text { water } \\
\end{array}$ & $\begin{array}{c}\text { Casajuana } \\
\text { et al., 2003 } \\
\text { Bottled } \\
\text { water } \\
\end{array}$ & $\begin{array}{c}\text { Peñalver } \boldsymbol{e t} \\
\text { al., } 2001 \\
\text { Bottled } \\
\text { water } \\
\end{array}$ & $\begin{array}{c}\text { Kayali } \\
\text { et al., 2006 } \\
\text { Bottled } \\
\text { water } \\
\end{array}$ & $\begin{array}{c}\text { Serodio } \text { et } \\
\text { al., 2006 } \\
\text { Bottled } \\
\text { water } \\
\end{array}$ & $\begin{array}{c}\text { Serodio et } \\
\boldsymbol{a l . ,}, 2006 \\
\text { Tap water }\end{array}$ & $\begin{array}{c}\text { Luks } \\
\text { et al., 2001 } \\
\text { Tap water } \\
\text { Poland } \\
\end{array}$ & $\begin{array}{c}\text { Luks } \\
\text { et al., 2001 } \\
\text { Tap water } \\
\text { Germany } \\
\end{array}$ & $\begin{array}{c}\text { Current } \\
\text { Study } \\
\text { Bottled } \\
\text { water } \\
\end{array}$ \\
\hline Samples number & 132 & 20 & 3 & 4 & 1 & 1 & 1 & 1 & 142 \\
\hline Phtalic acid (PhA) & 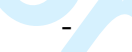 & - & - & - & - & - & - & - & 1.28 \\
\hline Dimethylphthalate (DMP) & - & 0.002 & ND & - & ND & 0.04 & - & - & 0.07 \\
\hline Diethylphthalate (DEP) & - & 0.254 & 0.24 & - & 0.04 & 0.19 & 0.16 & 0.20 & 0.17 \\
\hline Diisobutylphthalate (DiisoBP) & - & - & - & - & - & - & - & - & 0.20 \\
\hline Di-n-butyl- phthalate (DBP) & - & 0.047 & 0.10 & - & 0.35 & 0.52 & 0.64 & 0.38 & 0.21 \\
\hline Bis(2-ethylhexyl)phthalate (DEHP) & $8.5^{1}$ & 0.164 & 1.0 & ND & 0.17 & 0.06 & 0.06 & 0.05 & 0.02 \\
\hline
\end{tabular}

${ }^{\mathrm{l}}$ DEHP was only detected in two samples

ND not detected

- not analysed 
Table 2. Target analytes quartiles in $\left(\mu \mathrm{g} \mathrm{L}^{-1}\right)$ for glass and PET bottled water.

\begin{tabular}{ccccccccc}
\hline$\left(\boldsymbol{\mu g L} \mathbf{L}^{-1}\right)$ & $\begin{array}{c}\text { Quartiles } \\
(\boldsymbol{\%})\end{array}$ & PhA & DMP & DEP & DiisoBP & DBP & DEHP & Total \\
\hline \multirow{3}{*}{ GLASS } & 25 & $<$ LOD & $<$ LOQ & $<$ LOQ & 0.02 & 0.02 & $<$ LOQ & 0.13 \\
& 50 & $<$ LOD & 0.02 & 0.02 & 0.03 & 0.04 & $<$ LOQ & 0.19 \\
& 75 & $<$ LOD & 0.04 & 0.06 & 0.06 & 0.09 & $<$ LOQ & 0.36 \\
\hline \multirow{3}{*}{ PET } & 25 & 1.24 & $<$ LOQ & 0.14 & 0.221 & 0.17 & $<$ LOQ & 2.11 \\
& 50 & 2.20 & 0.06 & 0.22 & 0.32 & 0.23 & $<$ LOQ & 3.52 \\
& 75 & 3.50 & 0.10 & 0.35 & 0.45 & 0.52 & 0.02 & 4.81
\end{tabular}


2

3

4

5

6

7

8

9

10

11

12

13

14

15

16

17

18

19

20

21

22

23

24

25

26

27

28

29

30

31

32

33

34

35

36

37

38

39

40

41

42

43

44

45

46

47

48

49

50

51

52

53

54

55

56

57

58

59

60

Table 3. Minimum, maximum and quartiles values of the water consumption contribution to the RfDs for the PET bottled water.

\begin{tabular}{cccccc}
\hline & & RfD PhA $^{*}$ & RfD DEP & RfD DnBP & RfD DEHP \\
Reference value (mg/kg/day) & (EPA, 2006) & $\mathbf{2}$ & $\mathbf{0 . 8}$ & $\mathbf{0 . 1}$ & $\mathbf{0 . 0 2}$ \\
\hline & Min. & $<0.001$ & $<0.001$ & 0.003 & $<0.001$ \\
Samples RfD & $\mathbf{2 5}$ & 0.002 & 0.001 & 0.005 & $<0.001$ \\
contribution (\%) & $\mathbf{5 0}$ & 0.003 & 0.001 & 0.007 & $<0.001$ \\
& $\mathbf{7 5}$ & 0.005 & 0.001 & 0.015 & 0.001 \\
& Max. & 0.010 & 0.003 & 0.051 & 0.008 \\
\hline
\end{tabular}

For the PhA the RfD of the phthalic anhydre was considered 
Figure 1

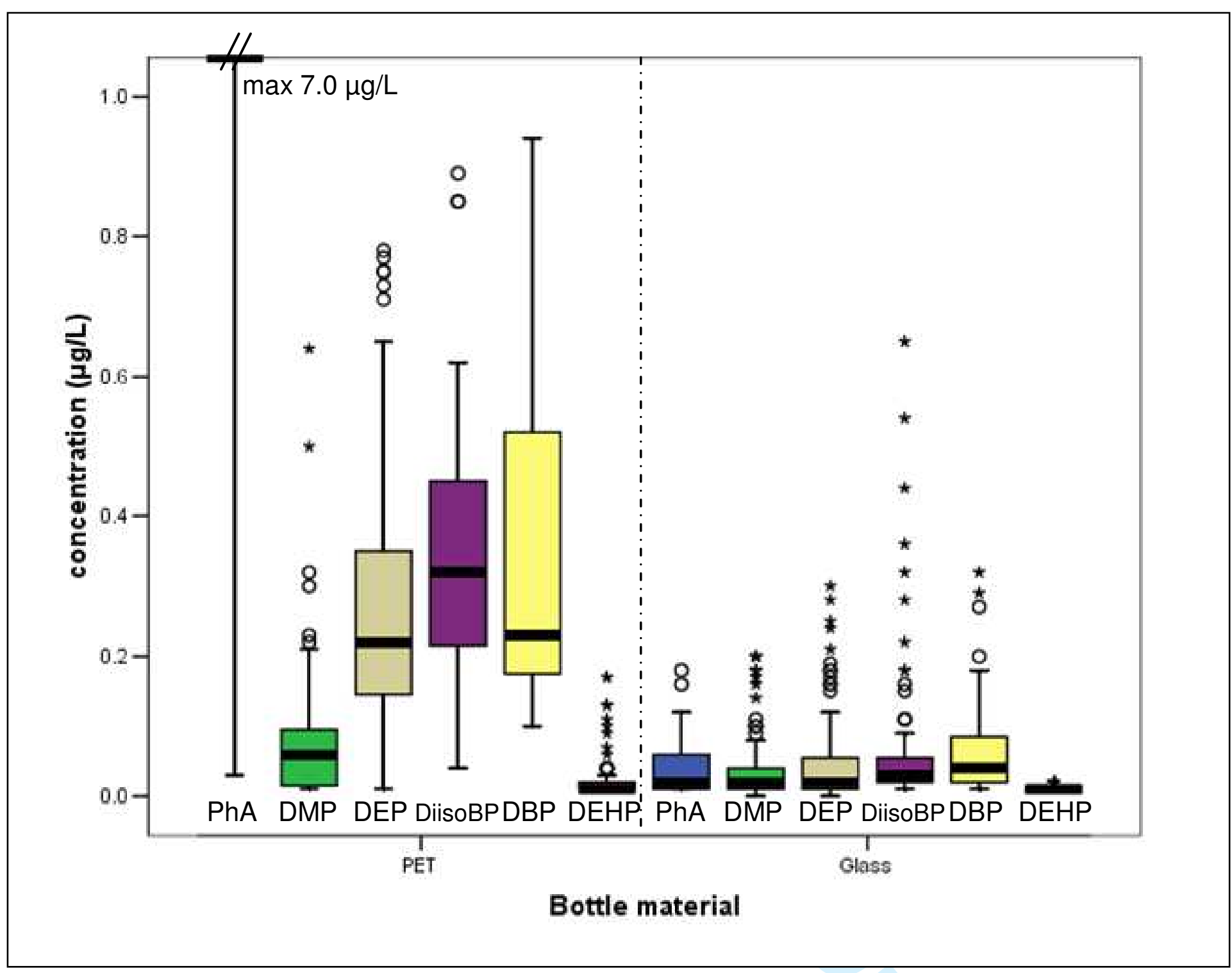

http://mc.manuscriptcentral.com/tfac Email: fac@tandf.co.uk 
Figure 2.

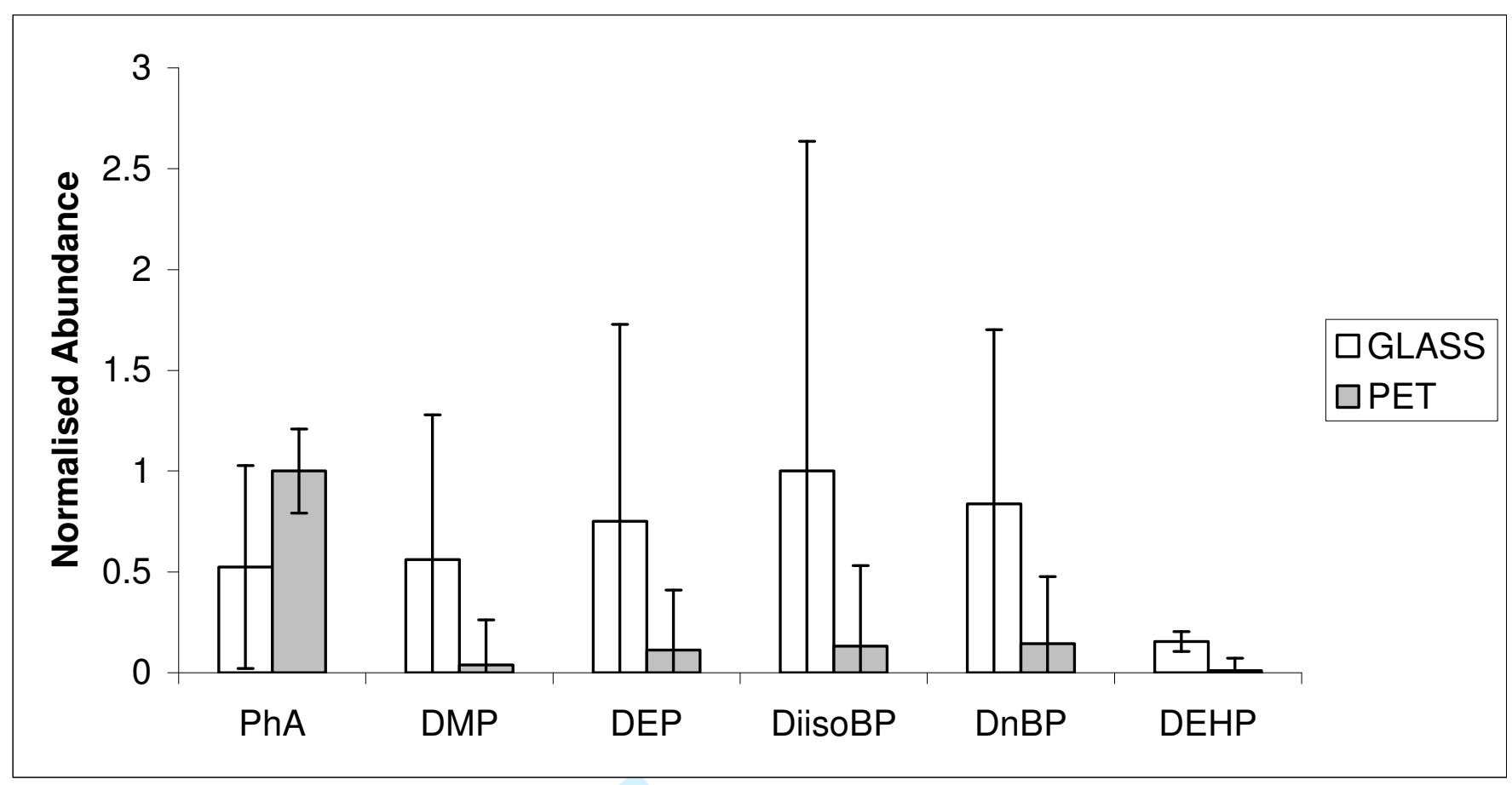

http://mc.manuscriptcentral.com/tfac Email: fac@tandf.co.uk 